\title{
Establishment of Enzyme Immunoassay for Measuring $\beta$-Methyldigoxin Levels in Human Serum by Specific Antiserum
}

\author{
Yasuhiko Higashi, * Naomi Watanabe, Toshiyuki Sasaki, and Youichi Fuji \\ Department of Analytical Chemistry, Faculty of Pharmaceutical Sciences, Hokuriku University; Ho-3, Kanagawa-machi, \\ Kanazawa 920-1181, Japan. Received March 15, 2002; accepted July 17, 2002
}

\begin{abstract}
We investigated the specificity of obtained antisera to $\beta$-methyldigoxin by the enzyme immunoassay. Three types of hapten-bovine serum albumin (BSA) conjugates were synthesized to obtain high specific antisera to $\beta$ methyldigoxin. The haptens were linked to the carrier protein through hemisuccinate at $\mathrm{C}-3^{\prime}$ and $\mathrm{C}-3^{\prime \prime}$ positions in the digitoxose chain and at $\mathrm{C}-12$ position in the aglycone. Anti- $\beta$-methyldigoxin $3^{\prime}$-hemisuccinate-BSA antiserum showed a low detection limit $(0.2 \mathrm{ng} / \mathrm{ml})$ and possessed high specificity for $\beta$-methyldigoxin, exhibiting low cross-reactions with digoxigenin bisdigitoxoside $(8.3 \%)$, dihydrodigoxin $(4.8 \%)$, digitoxin $(1.5 \%)$, and digoxigenin monodigitoxoside $(0.95 \%)$, except for cross-reaction with digoxin $(43 \%)$. Compared with commercial antidigoxin antiserum, clinically used to monitor $\beta$-methyldigoxin concentration in human serum, cross-reaction data of anti- $\beta$-methyldigoxin 3 '-hemisuccinate-BSA antiserum showed higher specificity for $\beta$-methyldigoxin. The intra-assay and inter-assay variations using this antiserum were less than $6.9 \%$ and $8.1 \%$, respectively. The recovery tests were good, within the range of 96.2-104.3\%. Phenyl boric acid (PBA) column treatment was effective to rapidly and selectively separate $\beta$-methyldigoxin from the mixture of $\beta$-methyldigoxin and its metabolites in human serum. The recovery tests of $\beta$-methyldigoxin with PBA column in human serum were about $110 \%$ and interference of metabolites of $\beta$-methyldigoxin was negligible. These results suggest that anti- $\beta$ methyldigoxin $3^{\prime}$-hemisuccinate-BSA antiserum and PBA column treatment are useful to more precisely monitor the unchanged type of $\boldsymbol{\beta}$-methyldigoxin concentration in human serum.
\end{abstract}

Key words $\beta$-methyldigoxin; anti- $\beta$-methyldigoxin 3 '-hemisuccinate-BSA antiserum; phenyl boric acid column; anti-digoxin antiserum; enzyme immunoassay; cross-reactivity

Cardiac glycosides are clinically used as an important drug for treatment of congestive heart failure and atrial fibrillation, and therapeutic monitoring of them has been performed, because their effective concentration in serum is very narrow. $\beta$-Methyldigoxin (MDx3) is a compound conjugating methyl group at C-4"' position of digoxin (Dx3), and it is a more absorptive drug compared with Dx3 after p.o. administration.

Immunoassay procedures have been used to monitor cardiac glycosides concentrations in serum. Recently, anti-Dx3 antibody has been clinically used to monitor MDx3 levels in human serum. ${ }^{1-3)}$ However, because administered MDx3 is metabolized to mainly $\mathrm{Dx} 3$, digoxigenin bisdigitoxoside (Dx2), digoxigenin monodigitoxoside (Dx1), digoxigenin (Dx0), and dihydrodigoxin (DihDx3) in the body, ${ }^{4-6)}$ low specificity of used antibodies is one of the most severe problems for measuring MDx3. To obtain a highly specific antibody, the binding position of hapten to carrier protein is a key point. Shimada et al. ${ }^{7)}$ and Thong et al. ${ }^{8)}$ used conjugates where the hapten was linked to the carrier protein at the $\mathrm{C}-12$ (or C-17) and C-22 positions, respectively. These antisera exhibited remarkable cross-reactivity with DihDx3, one of the metabolites. Previously, we reported preparation and antigenic properties of Dx3-bovine serum albumin (BSA) and digitoxin-BSA conjugates linked at the digitoxose $\mathrm{C}-3^{\prime}$ and C-3" positions using radioimmunoassay (RIA). ${ }^{9-11)}$ Our previous results suggested that antisera to these conjugates linked at the digitoxose $\mathrm{C}-3^{\prime}$ position showed higher specificity to metabolites. However, a more convenient and simple method is needed, because RIA uses radioactive substances and a special facility.

In this paper, we prepared MDx3-BSA conjugates possessing bridges at the hydroxyl groups of C-3', C- $3^{\prime \prime}$, or C-12 as binding positions in synthesizing antigens, and show spe- cific properties to MDx3 of three obtained antisera and commercial anti-Dx3 antiserum in enzyme immunoassay (EIA). Then, using a phenyl boric acid (PBA) column, which has the ability to adsorb compounds possessing cis-diol group in the chemical structure, ${ }^{12,13)}$ we carried out the pretreatment to separate MDx3 from mixtures of MDx3 and its metabolites in human serum and investigated the usefulness of a PBA column to monitor the unchanged type of MDx3.

\section{MATERIALS AND METHODS}

Materials MDx3 and DihDx3 were obtained from Boehringer Mannheim (Mannheim, Germany), spironolactone, BSA (fraction V), anti-rabbit IgG antiserum developed in goat, and anti-Dx3 antiserum from Sigma Chemical Co. (St. Louis, MO, U.S.A.), Dx3 from Aldrich (Milwaukee, WI, U.S.A.). Sephadex LH-20 were purchased from Pharmacia Fine Chemicals (Uppsala, Sweden), Reversed-phase $\mathrm{KC}_{18}$ plates $(5 \times 10 \mathrm{~cm})$ for TLC from Whatman (Clifton, NJ, U.S.A.), Kiesel-gel 60 for column chromatography and high performance thin-layer chromatography (HPTLC) plates $(5 \times 10 \mathrm{~cm})$ from E. Merck (Darmstadt, Germany). Digitoxin, $\beta$-D-galactosidase (EC 3.2.1.23) from Escherichia coli, and 4-methylumbelliferyl- $\beta$-D-galactopyranoside, and other general reagents were obtained from Wako Pure Chemical Industries (Osaka, Japan). Dx0, Dx1, and Dx2 were prepared by hydrolysis of Dx3 according to the methods of Kaiser and co-workers. ${ }^{14)}$ Dx0 12-hemisuccinate was synthesized by the method of Ikeda and Fujii. ${ }^{9}$ PBA column and VacElut Vacuum Manifold were purchased from Varian (Harbor City, U.S.A.) and GL Science (Tokyo, Japan), respectively.

Apparatus All melting points were determined with a Yanagimoto micro hot-stage apparatus and are uncorrected. 
Optical rotations were measured with a JASCO DIP-370 digital polarimeter. FAB-MS measurements were made on a JEOL HX-100 instrument equipped with a FAB ion source using glycerol and $\mathrm{NaCl}$ as the matrix agents. UV spectra were obtained with a Shimadzu UV-3000 recording spectrophotometer. ${ }^{1} \mathrm{H}-\mathrm{NMR}$ spectra were recorded using tetramethylsilane as an internal standard on a JEOL EX-90A spectrometer at $90 \mathrm{MHz}$. Abbreviations used: $\mathrm{s}=$ singlet, $\mathrm{d}=$ doublet, and $\mathrm{m}=$ multiplet.

MDx3 3'-Hemisuccinate (1) To a solution of MDx3 $(1.2 \mathrm{~g}, 1.5 \mathrm{mmol})$ in pyridine $(70 \mathrm{ml})$, succinic anhydride (1.2 $\mathrm{g}, 12 \mathrm{mmol}$ ) was added, and the mixture was allowed to stand at $70^{\circ} \mathrm{C}$ for $73.5 \mathrm{~h}$. The reaction mixture was extracted with AcOEt, and the organic layer was washed with $1 \% \mathrm{HCl}$, $1 \% \mathrm{NaHCO}_{3}$, and $\mathrm{H}_{2} \mathrm{O}$, then dried over anhydrous $\mathrm{Na}_{2} \mathrm{SO}_{4}$. The aqueous layer was percolated through an Amberlite XAD-2 column $(80 \times 1.6 \mathrm{~cm}$ i.d.). The column was washed with $\mathrm{H}_{2} \mathrm{O}$, then the desired material, which could not be extracted with AcOEt, was eluted with $\mathrm{MeOH}$. The AcOEt extract and the $\mathrm{MeOH}$ eluate were combined and submitted to silica-gel column $(133 \times 2.5 \mathrm{~cm}$ i.d.) chromatography using $\mathrm{CHCl}_{3}-\mathrm{MeOH}-\mathrm{AcOH}(95: 5: 0.2, \mathrm{v} / \mathrm{v})$ as a mobile phase. The eluate corresponding to $\mathbf{1}$ was further purified on a Sephadex LH-20 column $(47 \times 1.5 \mathrm{~cm}$ i.d.) using $\mathrm{MeOH}$ as an eluent. The eluate was recrystallized from acetone-hexane $(1: 2, \mathrm{v} / \mathrm{v})$ to give $\mathbf{1}(97 \mathrm{mg}, 7.2 \%)$ as a colorless amorphous solid. mp $151-154^{\circ} \mathrm{C}$. $[\alpha]_{\mathrm{D}}^{21}+34.4^{\circ}(c=0.25, \mathrm{MeOH})$. Anal. Calcd for $\mathrm{C}_{46} \mathrm{H}_{70} \mathrm{O}_{17} \cdot 1 / 2 \mathrm{H}_{2} \mathrm{O}: \mathrm{C}, 61.11 ; \mathrm{H}, 7.92$. Found: C, 61.15; H, 7.83. FAB-MS $m / z$ : $939[\mathrm{M}-\mathrm{H}+$ $2 \mathrm{Na}]^{+}, 917[\mathrm{M}+\mathrm{Na}]^{+}, 773$. [digoxigenin bisdigitoxoside $3^{\prime}$ -

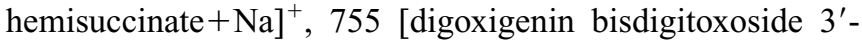
hemisuccinate $\left.-\mathrm{H}_{2} \mathrm{O}+\mathrm{Na}\right]^{+}, 643$ [digoxigenin monodigitoxoside $3^{\prime}$-hemisuccinate $\left.+\mathrm{Na}\right]^{+}, 621$ [digoxigenin monodigitoxoside. $3^{\prime}$-hemisuccinate $\left.+\mathrm{H}\right]^{+}, 603$ [digoxigenin monodigitoxoside $3^{\prime}$-hemisuccinate $\left.-\mathrm{H}_{2} \mathrm{O}+\mathrm{H}\right]^{+}$. UV $\lambda_{\max }(\mathrm{MeOH})$ $\mathrm{nm}(\varepsilon): 218$ (12900). ${ }^{1} \mathrm{H}-\mathrm{NMR}\left(\mathrm{CDCl}_{3}\right) \delta: 0.80(3 \mathrm{H}, \mathrm{s}, 18-$ $\left.\mathrm{CH}_{3}\right), 0.92\left(3 \mathrm{H}, \mathrm{s}, 19-\mathrm{CH}_{3}\right), 1.21-1.27\left(9 \mathrm{H}, \mathrm{m}\right.$, sugar- $\left.\mathrm{CH}_{3}\right)$, $2.67\left(4 \mathrm{H}\right.$, br s, $\left.-\mathrm{CO}\left(\mathrm{CH}_{2}\right)_{2} \mathrm{CO}-\right), 3.41\left(3 \mathrm{H}, \mathrm{s},-\mathrm{OCH}_{3}\right), 5.38$ $\left(1 \mathrm{H}, \mathrm{m}, 3^{\prime}-\mathrm{H}\right), 5.95(1 \mathrm{H}, \mathrm{s}, 22-\mathrm{H})$.

MDx3 3"-Hemisuccinate (2) To a solution of MDx3 $(1.3 \mathrm{~g}, 1.6 \mathrm{mmol})$ in pyridine $(90 \mathrm{ml})$, succinic anhydride $(1.2 \mathrm{~g}, 12 \mathrm{mmol})$ was added, and the mixture was allowed to stand at $60{ }^{\circ} \mathrm{C}$ for $68 \mathrm{~h}$. The reaction mixture was treated in the same manner as described in 1. The AcOEt extract and the $\mathrm{MeOH}$ eluate were combined and submitted to silica-gel column $(133 \times 2.5 \mathrm{~cm}$ i.d. $)$ chromatography using $\mathrm{CHCl}_{3}-$ $\mathrm{MeOH}-\mathrm{H}_{2} \mathrm{O}(92: 8: 0.5, \mathrm{v} / \mathrm{v})$ as a mobile phase. The eluate corresponding to $\mathbf{2}$ was further purified on a Sephadex LH20 column $(47 \times 1.5 \mathrm{~cm}$ i.d.) using $\mathrm{MeOH}$ as an eluent. The eluate was recrystallized from acetone-hexane $(1: 2, \mathrm{v} / \mathrm{v})$ to give $2(56 \mathrm{mg}, 4.0 \%)$ as a colorless amorphous solid. $\mathrm{mp}$ $149-152^{\circ} \mathrm{C} .[\alpha]_{\mathrm{D}}^{21}+37.3^{\circ}(c=0.25, \mathrm{MeOH})$. Anal. Calcd for $\mathrm{C}_{46} \mathrm{H}_{70} \mathrm{O}_{17} \cdot 1 / 2 \mathrm{H}_{2} \mathrm{O}$ : C, 61.73; $\mathrm{H}, 7.88$. Found: $\mathrm{C}, 61.55$; $\mathrm{H}, 7.79$. FAB-MS $m / z$ : $939[\mathrm{M}-\mathrm{H}+2 \mathrm{Na}]^{+}, 917[\mathrm{M}+\mathrm{Na}]^{+}$, 773. [digoxigenin bisdigitoxoside $3^{\prime \prime}$-hemisuccinate $\left.+\mathrm{Na}\right]^{+}$, 755 [digoxigenin bisdigitoxoside $3^{\prime \prime}$-hemisuccinate $-\mathrm{H}_{2} \mathrm{O}+$ $\mathrm{Na}^{+}, \quad 543$ [digoxigenin monodigitoxoside $\left.+\mathrm{Na}\right]^{+}, \quad 525$ [digoxigenin monodigitoxoside $\left.-\mathrm{H}_{2} \mathrm{O}+\mathrm{Na}\right]^{+}, 521$ [digoxigenin monodigitoxoside $+\mathrm{H}]^{+}, 502$ [digoxigenin monodigi-

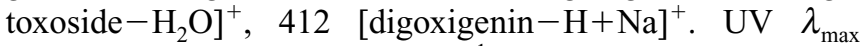
$(\mathrm{MeOH}) \mathrm{nm}(\varepsilon): 217$ (12900). ${ }^{1} \mathrm{H}-\mathrm{NMR}\left(\mathrm{CDCl}_{3}\right) \delta: 0.80$ $\left(3 \mathrm{H}, \mathrm{s}, 18-\mathrm{CH}_{3}\right), 0.93\left(3 \mathrm{H}, \mathrm{s}, 19-\mathrm{CH}_{3}\right), 1.24-1.37(9 \mathrm{H}, \mathrm{m}$, sugar- $\left.\mathrm{CH}_{3}\right), 2.68\left(4 \mathrm{H}\right.$, br s, $\left.-\mathrm{CO}\left(\mathrm{CH}_{2}\right)_{2} \mathrm{CO}-\right), 3.40(3 \mathrm{H}, \mathrm{s}$, $\left.-\mathrm{OCH}_{3}\right), 5.43\left(1 \mathrm{H}, \mathrm{m}, 3^{\prime \prime}-\mathrm{H}\right), 5.94(1 \mathrm{H}, \mathrm{s}, 22-\mathrm{H})$.

MDx3 12-Hemisuccinate (3) To a solution of MDx3 $(1.0 \mathrm{~g}, 1.3 \mathrm{mmol})$ in pyridine $(70 \mathrm{ml})$, succinic anhydride $(4.0 \mathrm{~g}, 40 \mathrm{mmol})$ was added, and the mixture was allowed to stand at $60^{\circ} \mathrm{C}$ for $73 \mathrm{~h}$. The reaction mixture was treated in the same manner as described in 1. The AcOEt extract and the $\mathrm{MeOH}$ eluate were combined and submitted to silica-gel column $(133 \times 2.5 \mathrm{~cm}$ i.d. $)$ chromatography using $\mathrm{CHCl}_{3}-$ $\mathrm{MeOH}-\mathrm{H}_{2} \mathrm{O}(92: 8: 0.5, \mathrm{v} / \mathrm{v})$ as a mobile phase. The eluate corresponding to $\mathbf{3}$ was further purified on a Sephadex LH20 column $(47 \times 1.5 \mathrm{~cm}$ i.d.) using $\mathrm{MeOH}$ as an eluent. The eluate was recrystallized from acetone-hexane $(1: 2, \mathrm{v} / \mathrm{v})$ to give $3(153 \mathrm{mg}, 13.6 \%)$ as a colorless amorphous solid. mp $157-160^{\circ} \mathrm{C} .[\alpha]_{\mathrm{D}}^{22}-103.4^{\circ}(c=0.20, \mathrm{MeOH})$. Anal. Calcd for $\mathrm{C}_{46} \mathrm{H}_{70} \mathrm{O}_{17}: \mathrm{C}, 61.73 ; \mathrm{H}, 7.88$. Found: $\mathrm{C}, 61.37 ; \mathrm{H}, 8.12$. FAB-MS $m / z: 939[\mathrm{M}-\mathrm{H}+2 \mathrm{Na}]^{+}, 917[\mathrm{M}+\mathrm{Na}]^{+}, 899$ $\left[\mathrm{M}-\mathrm{H}_{2} \mathrm{O}+\mathrm{Na}\right]^{+}, 625$ [digoxigenin monodigitoxoside 12hemisuccinate $\left.-\mathrm{H}_{2} \mathrm{O}+\mathrm{Na}\right]^{+}$, EI-MS m/z: 472 [digoxigenin 12-hemisuccinate $\left.-\mathrm{H}_{2} \mathrm{O}\right]^{+}$. UV $\lambda_{\max }(\mathrm{MeOH}) \mathrm{nm}(\varepsilon): 217$ (13700). ${ }^{1} \mathrm{H}-\mathrm{NMR}\left(\mathrm{CDCl}_{3}\right) \delta$ : 0.89 and $0.92\left(6 \mathrm{H}, \mathrm{s}, 18-\mathrm{CH}_{3}\right.$ or $\left.19-\mathrm{CH}_{3}\right), 1.22-1.30\left(9 \mathrm{H}, \mathrm{m}\right.$, sugar $\left.-\mathrm{CH}_{3}\right), 2.65(4 \mathrm{H}$, br s, $\left.-\mathrm{CO}\left(\mathrm{CH}_{2}\right)_{2} \mathrm{CO}-\right), 3.41\left(3 \mathrm{H}, \mathrm{s},-\mathrm{OCH}_{3}\right), 5.97(1 \mathrm{H}, \mathrm{s}, 22-\mathrm{H})$.

Partial Hydrolysis of MDx3, 1, 2, or 3 To a solution of $\mathrm{MDx} 3, \mathbf{1}, \mathbf{2}$, or 3 (ca. $2.0 \mathrm{mg})$ in $\mathrm{MeOH}(0.52 \mathrm{ml}), 0.05 \mathrm{M}$ $\mathrm{HCl}(0.08 \mathrm{ml})$ was added, and the mixture was allowed to stand at $60^{\circ} \mathrm{C}$ for $4 \mathrm{~h}$. The reaction mixture was then extracted with AcOEt $(3 \mathrm{ml})$ and the extract was washed with $\mathrm{H}_{2} \mathrm{O}$. After evaporation of the solvent, the residue was spotted on TLC plates.

MDx3 3'-Hemisuccinate $p$-Nitrophenyl Ester (4) Dicyclohexylcarbodiimide (DCC, $43 \mathrm{mg}, 0.21 \mathrm{mmol}$ ) was added to a solution of $1(80 \mathrm{mg}, 0.089 \mathrm{mmol})$ and $p$-nitrophenol $(410 \mathrm{mg}, 2.9 \mathrm{mmol})$ in dioxane $(13 \mathrm{ml})$, and the mixture was stirred at room temperature for $8 \mathrm{~h}$. After evaporation of the solvent, the crude product obtained was submitted to silicagel column $(47 \times 1.5 \mathrm{~cm}$ i.d. $)$ chromatography using hexaneAcOEt $(1: 2, \mathrm{v} / \mathrm{v})$ as a mobile phase, and $4(61 \mathrm{mg}, 67.2 \%)$ was obtained as a yellow oil. ${ }^{1} \mathrm{H}-\mathrm{NMR}\left(\mathrm{CDCI}_{3}\right) \delta$ : $0.79(3 \mathrm{H}$, s, 18- $\left.\mathrm{CH}_{3}\right), 0.93\left(3 \mathrm{H}, \mathrm{s}, 19-\mathrm{CH}_{3}\right), 1.21-1.27(9 \mathrm{H}$, m, sugar$\left.\mathrm{CH}_{3}\right), 2.72-2.95\left(4 \mathrm{H}, \mathrm{m},-\mathrm{CO}\left(\mathrm{CH}_{2}\right)_{2} \mathrm{CO}-\right), 3.41(3 \mathrm{H}, \mathrm{s}$, $\left.-\mathrm{OCH}_{3}\right), 5.39\left(1 \mathrm{H}, \mathrm{m}, 3^{\prime}-\mathrm{H}\right), 5.93(1 \mathrm{H}, \mathrm{s}, 22-\mathrm{H}), 7.29,8.27$ (each $2 \mathrm{H}, \mathrm{d}, J=9 \mathrm{~Hz}$, aromatic $\mathrm{H}$ ).

MDx3 3"-Hemisuccinate p-Nitrophenyl Ester (5) DCC (26 mg, $0.12 \mathrm{mmol})$ was added to a solution of 2 (41 mg, $0.045 \mathrm{mmol})$ and $p$-nitrophenol (203 $\mathrm{mg}, 1.4 \mathrm{mmol}$ ) in dioxane $(17 \mathrm{ml})$, and the mixture was stirred at room temperature for $6 \mathrm{~h}$. After evaporation of the solvent, the crude product obtained was submitted to silica-gel column $(15 \times 0.7 \mathrm{~cm}$ i.d. $)$ chromatography using hexane-AcOEt $(1: 1, \mathrm{v} / \mathrm{v})$ as a mobile phase, and 5 (20 mg, 44\%) was obtained as a yellow oil. ${ }^{1} \mathrm{H}$ NMR $\left(\mathrm{CDCI}_{3}\right) \delta: 0.79\left(3 \mathrm{H}, \mathrm{s}, 18-\mathrm{CH}_{3}\right), 0.92(3 \mathrm{H}, \mathrm{s}, 19-$ $\left.\mathrm{CH}_{3}\right), 1.17-1.29\left(9 \mathrm{H}, \mathrm{m}\right.$, sugar- $\left.\mathrm{CH}_{3}\right), 2.82-2.93(4 \mathrm{H}, \mathrm{m}$, $\left.-\mathrm{CO}\left(\mathrm{CH}_{2}\right)_{2} \mathrm{CO}-\right), 3.40\left(3 \mathrm{H}, \mathrm{s},-\mathrm{OCH}_{3}\right), 5.41\left(1 \mathrm{H}, \mathrm{m}, 3^{\prime \prime}-\mathrm{H}\right)$, $5.93(1 \mathrm{H}, \mathrm{s}, 22-\mathrm{H}), 7.30,8.27$ (each $2 \mathrm{H}, \mathrm{d}, J=9 \mathrm{~Hz}$, aromatic $\mathrm{H})$.

MDx3 12-Hemisuccinate $\boldsymbol{p}$-Nitrophenyl Ester (6) DCC $(76 \mathrm{mg}, 0.37 \mathrm{mmol})$ in dioxane $(40 \mathrm{ml})$ was gradually added to a solution of $3(152 \mathrm{mg}, 0.17 \mathrm{mmol})$ and $p$-nitrophenol $(754 \mathrm{mg}, 5.4 \mathrm{mmol})$ in dioxane $(20 \mathrm{ml})$, and the mixture was 
stirred at room temperature for $7 \mathrm{~h}$. After evaporation of the solvent, the crude product obtained was submitted to silicagel column $(47 \times 1.5 \mathrm{~cm}$ i.d.) chromatography using hexaneAcOEt $(1: 2, \mathrm{v} / \mathrm{v})$ as a mobile phase, and $6(83 \mathrm{mg}, 48.1 \%)$ was obtained as a yellow oil. ${ }^{1} \mathrm{H}-\mathrm{NMR}\left(\mathrm{CDCI}_{3}\right) \delta: 0.90$ and $0.91\left(6 \mathrm{H}, \mathrm{s}, 18-\mathrm{CH}_{3}\right.$ or $\left.19-\mathrm{CH}_{3}\right), 1.19-1.30(9 \mathrm{H}, \mathrm{m}$, sugar$\left.\mathrm{CH}_{3}\right), 2.71-2.81\left(4 \mathrm{H}, \mathrm{m},-\mathrm{CO}\left(\mathrm{CH}_{2}\right)_{2} \mathrm{CO}-\right), 3.42(3 \mathrm{H}, \mathrm{s}$, $\left.-\mathrm{OCH}_{3}\right), 5.98(1 \mathrm{H}, \mathrm{s}, 22-\mathrm{H}), 7.15,8.27($ each $2 \mathrm{H}, \mathrm{d}, J=9 \mathrm{~Hz}$, aromatic $\mathrm{H})$.

MDx3 3'-Hemisuccinate-BSA (7), MDx3 3"-Hemisuccinate-BSA (8), and MDx3 12-Hemisuccinate-BSA (9) A solution of BSA $(50 \mathrm{mg})$ in $0.05 \mathrm{M}$ phosphate buffer $(\mathrm{pH} 7.4$, $0.5 \mathrm{ml}$ ) was added to a solution of $5(40 \mathrm{mg}, 0.039 \mathrm{mmol}), 6$ $(20 \mathrm{mg}, 0.020 \mathrm{mmol})$, or $7(52 \mathrm{mg} 0.051 \mathrm{mmol})$ in pyridine $(0.5 \mathrm{ml})$, and then these mixtures were stirred at room temperature for $8 \mathrm{~h}$ to synthesize 7 or $\mathbf{8}$ and for $5 \mathrm{~h}$ to synthesize 9. The resulting solutions were dialyzed against a constant flow of cold water (201) at room temperature overnight. Lyophilization of these solutions afforded 7, 8, or 9 as a fluffy powder.

Preparation of $\boldsymbol{\beta}$-D-Galactosidase-Labeled Antigens A solution of $4(5.8 \mathrm{mg}), \mathbf{5}(6.0 \mathrm{mg})$, or $\mathbf{6}(2.0 \mathrm{mg})$ in dioxan $(0.5 \mathrm{ml})$ were incubated with a solution of $\beta$-D-galactosidase $(2.1 \mathrm{mg})$ in $1 \mathrm{ml}$ of $0.05 \mathrm{M}$ phosphate buffer $(\mathrm{pH} \mathrm{9.0)}$ for $4 \mathrm{~h}$ at $4{ }^{\circ} \mathrm{C}$. Then, the reaction mixtures were submitted to Sephadex G-25 column $(45 \times 1.5 \mathrm{~cm}$ i.d. $)$ chromatography using $0.05 \mathrm{~m}$ phosphate buffer $(\mathrm{pH} 7.0)$ as a mobile phase. $2.7 \mathrm{ml}$ of fractions were collected, and fractions representing the main peak of the enzyme activity were further submitted to Sephadex G-100 column $(45 \times 1.5 \mathrm{~cm}$ i.d.) chromatography using $0.05 \mathrm{M}$ phosphate buffer $(\mathrm{pH} 7.0)$ as a mobile phase. Fractions representing the main peak of the enzyme activity were chosen as a labeled antigen in EIA. On the other hand, each fraction was spotted on TLC plates using $\mathrm{CH}_{3} \mathrm{Cl}-\mathrm{MeOH}-\mathrm{AcOH}(90: 10: 0.8, \mathrm{v} / \mathrm{v})$ as a developing solvent, and coloration for steroid compounds at origin was observed by spraying with concentrated $\mathrm{H}_{2} \mathrm{SO}_{4}$. From these results, three enzyme-labeled antigens (MDx3 3'-, 3"-, and 12hemisuccinate- $\beta$-D-galactosidase) were obtained.

Immunization Procedure Three domestic strains of male albino rabbits were used for immunization with each hapten-BSA conjugate. The antigen $(3 \mathrm{mg}$ ) was dissolved in sterile isotonic saline $(0.9 \mathrm{ml})$ and emulsified with complete Freund's adjuvant $(2.1 \mathrm{ml})$. The emulsion was injected into multiple subcutaneous sites along both sides of the back of each rabbit. The procedure was repeated at intervals of two weeks for five months and then the rabbits were boosted twice a month. After confirmation of the increase in the antibody titer, blood was collected from the marginal ear veins. Sera were separated by centrifugation at $1400 \times \boldsymbol{g}$ for $10 \mathrm{~min}$ and stored at $-18^{\circ} \mathrm{C}$ in small aliquots. The antisera were thawed, diluted with phosphate saline buffer $(\mathrm{pH}$ 7.4) and used in the assay.

EIA Method EIA is based on the principle of competition between enzyme-labeled and unlabeled drugs for an antibody, followed by measurement of the marker enzyme activity of the immune precipitate. EIA was performed in phosphate saline buffer ( $\mathrm{pH}$ 7.3). Phosphate saline buffer was adjusted to $\mathrm{pH} 7.3$ by addition of a solution containing $\mathrm{NaH}_{2} \mathrm{PO}_{4}$ (3.9 g), $\mathrm{NaCl}(4.5 \mathrm{~g}), \mathrm{NaN}_{3}(0.5 \mathrm{~g}), \mathrm{MgCl}_{2}$ (0.005 g), and BSA $(0.5 \mathrm{~g})$ in $\mathrm{H}_{2} \mathrm{O}(500 \mathrm{ml})$ to a solution containing

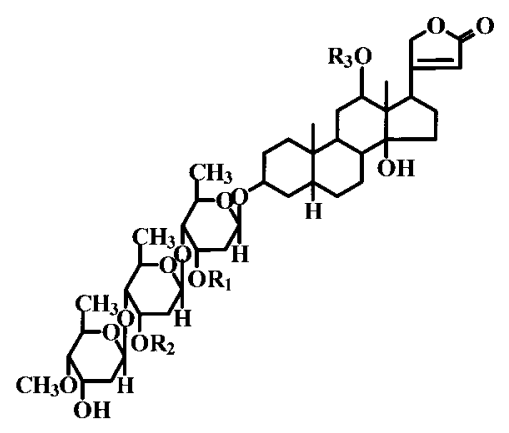

$$
\begin{aligned}
& \text { MDx3: } \mathrm{R}_{1}=\mathrm{R}_{2}=\mathrm{R}_{3}=\mathrm{H} \\
& \text { 1: } \mathrm{R}_{1}=\mathrm{CO}\left(\mathrm{CH}_{2}\right)_{2} \mathrm{COOH}, \mathrm{R}_{2}=\mathrm{R}_{3}=\mathrm{H} \\
& \text { 2: } \mathrm{R}_{1}=\mathrm{R}_{3}=\mathrm{H}, \mathrm{R}_{2}=\mathrm{CO}\left(\mathrm{CH}_{2}\right)_{2} \mathrm{COOH} \\
& \text { 3: } \mathrm{R}_{1}=\mathrm{R}_{2}=\mathrm{H}, \mathrm{R}_{3}=\mathrm{CO}\left(\mathrm{CH}_{2}\right)_{2} \mathrm{COOH} \\
& \text { 4: } \mathrm{R}_{1}=\mathrm{CO}\left(\mathrm{CH}_{2}\right)_{2} \mathrm{COO}\left(\mathrm{NO}_{2}, \mathrm{R}_{2}=\mathrm{R}_{3}=\mathrm{H}\right. \\
& \text { 5: } \mathrm{R}_{1}=\mathrm{R}_{3}=\mathrm{H}, \mathrm{R}_{2}=\mathrm{CO}\left(\mathrm{CH}_{2}\right)_{2} \mathrm{COO} \text { O }-\mathrm{NO}_{2} \\
& \text { 6: } \mathrm{R}_{1}=\mathrm{R}_{2}=\mathrm{H}, \mathrm{R}_{3}=\mathrm{CO}\left(\mathrm{CH}_{2}\right)_{2} \mathrm{COO} \mathrm{O}-\mathrm{NO}_{2} \\
& \text { 7: } \mathrm{R}_{1}=\mathrm{CO}\left(\mathrm{CH}_{2}\right)_{2} \mathrm{CONH}-\mathrm{BSA}_{2} \mathrm{R}_{2}=\mathrm{R}_{3}=\mathrm{H} \\
& \text { 8: } \mathrm{R}_{1}=\mathrm{R}_{3}=\mathrm{H}, \mathrm{R}_{2}=\mathrm{CO}\left(\mathrm{CH}_{2}\right)_{2} \mathrm{CONH}-\mathrm{BSA} \\
& \text { 9: } \mathrm{R}_{1}=\mathrm{R}_{2}=\mathrm{H}, \mathrm{R}_{3}=\mathrm{CO}\left(\mathrm{CH}_{2}\right)_{2} \mathrm{CONH}-\mathrm{BSA}
\end{aligned}
$$

Chart 1. Chemical Structures of Synthesized Compounds

$\mathrm{K}_{2} \mathrm{HPO}_{4}(8.7 \mathrm{~g}), \mathrm{NaCl}(9.0 \mathrm{~g}), \mathrm{NaN}_{3}(1.0 \mathrm{~g}), \mathrm{MgCl}_{2}(0.01 \mathrm{~g})$, and $\mathrm{BSA}(1.0 \mathrm{~g})$ in $\mathrm{H}_{2} \mathrm{O}(1000 \mathrm{ml})$. Standard samples $(0.2 \mathrm{ml})$ of $\mathrm{MDx} 3(0.2-20 \mathrm{ng} / \mathrm{ml})$ and diluted antiserum $(0.1 \mathrm{ml})$ were mixed and incubated for $2.5 \mathrm{~h}$ at $4{ }^{\circ} \mathrm{C}$. Then, $0.1 \mathrm{ml}$ of synthetic enzyme-labeled antigens (diluted $1: 1200$ in phosphate saline buffer) was added and incubated for $0.5 \mathrm{~h}$ at $4{ }^{\circ} \mathrm{C}$. $0.2 \mathrm{ml}$ of goat anti-rabbit $\mathrm{IgG}$ antiserum (1.67\%) and $0.1 \mathrm{ml}$ of normal rabbit serum $(1 \%)$ were added and allowed to stand for $12 \mathrm{~h}$ at $4{ }^{\circ} \mathrm{C}$. Mixtures were centrifuged at $1600 \times \mathbf{g}$ for $20 \mathrm{~min}$, the supernatant was aspirated, and the immune precipitate was twice washed by $1 \mathrm{ml}$ of phosphate saline buffer. The activity of enzyme conjugate bound to each tube was then measured by the addition of $0.5 \mathrm{ml}$ of 4-methylumbelliferyl- $\beta$-D-galactopyranoside $\left(2.0 \times 10^{-5} \mathrm{M}\right)$, followed by incubation of the tubes at $30^{\circ} \mathrm{C}$ for $3 \mathrm{~h}$ after preincubation of $0.5 \mathrm{ml}$ of phosphate saline buffer at $30^{\circ} \mathrm{C}$ for $3 \mathrm{~min}$. The enzyme reaction was stopped by addition of $2.0 \mathrm{ml}$ of glycine- $\mathrm{NaOH}$ buffer $(0.1 \mathrm{M}, \mathrm{pH} 10.3)$ to each tube, and the resulting 4-methylumbelliferone was measured by spectrofluorometry at wavelengths of $362 \mathrm{~nm}$ for excitation and $446 \mathrm{~nm}$ for emission using a fluorescence spectrophotometer (F-2000, Hitachi, Tokyo, Japan).

Cross-Reaction Study The antisera raised against 7, 8, and 9, and commercial anti-Dx3 antiserum were abbreviated to Antiserum-A, Antiserum-B, Antiserum-C, and Antiserum$\mathrm{D}$, respectively. The specificities of these antisera were tested by calculating the percentage cross-reactivity with various compounds. Cross-reactivity was determined by the abovementioned assay procedure, by comparing the concentrations of MDx3 and test compounds necessary for a 50\% displacement of the antibody-bound enzyme-labeled MDx3.

Extraction of MDx3 and Its Metabolites in Human Serum $0.2 \mathrm{ml}$ of human serum containing $\mathrm{MDx} 3, \mathrm{Dx} 3$, Dx2, Dx1, Dx0, and DihDx3, $0.1 \mathrm{ml}$ of boric acid (10 mM), and $0.1 \mathrm{ml}$ of $\mathrm{NH}_{4} \mathrm{OH}(0.3 \%)$ were mixed and the mixtures were extracted into $2 \mathrm{ml}$ of AcOEt at two times. Then, each $1.8 \mathrm{ml}$ of AcOEt phase was combined, evaporated with a 
concentrator (TAITEC, Saitama, Japan), and $1 \mathrm{ml}$ of $\mathrm{CH}_{3} \mathrm{CN}$ was added to the residue.

Separation of MDx3 Using PBA Column Separation procedures were as follows. $1 \mathrm{ml}$ of $\mathrm{HCl}(0.1 \mathrm{M})$ was added to the column, which was allowed to completely run through with VacElut (GL Science, Tokyo, Japan). Then, $4 \mathrm{ml}$ of $\mathrm{NH}_{4} \mathrm{OH}(1.0 \%), 2 \mathrm{ml}$ of $\left(\mathrm{NH}_{4}\right)_{2} \mathrm{SO}_{4}(0.01 \mathrm{M}, \mathrm{pH} 8.5)$, and $2 \mathrm{ml}$ of $\mathrm{NH}_{4} \mathrm{OH}(0.3 \%)$ were passed through the column, successively. The above $\mathrm{CH}_{3} \mathrm{CN}$ solution was added to the column, allowed to completely run at gravity, and the column was extracted four times with $1 \mathrm{ml}$ of $\mathrm{CH}_{3} \mathrm{CN}$. About $4 \mathrm{ml}$ of collected $\mathrm{CH}_{3} \mathrm{CN}$ solution was evaporated with a concentrator, and was used in the assay.

\section{RESULTS AND DISCUSSION}

Initially, the synthesis of MDx3 3'-, 3"-, and 12-hemisuccinate-BSA conjugates (7-9) was carried out. In the previous papers of this series, we reported the preparation of digitoxin $3^{\prime}$ - and $3^{\prime \prime}$-hemisuccinates from digitoxin and Dx3 $3{ }^{\prime}$ and $3^{\prime \prime}$-hemisuccinates from Dx3 by utilizing the reactivities of the hydroxyl groups in the digitoxose moiety. ${ }^{9-11)}$ In a similar way, MDx3 3'-, 3"-, and 12-hemisuccinates (1-3) could be prepared from MDx3 with succinic anhydride in pyridine. The resulting crude product was submitted to silicagel column chromatography using a $\mathrm{CHCl}_{3}-\mathrm{MeOH}-\mathrm{AcOH}$ $(95: 5: 0.2, \mathrm{v} / \mathrm{v})$ or $\mathrm{CHCl}_{3}-\mathrm{MeOH}-\mathrm{H}_{2} \mathrm{O}(92: 8: 0.5, \mathrm{v} / \mathrm{v})$ as an eluent, and the chromatography provided a satisfactory separation of three isomeric hemisuccinates. In the ${ }^{1} \mathrm{H}-\mathrm{NMR}$ spectra of $\mathbf{1}, \mathbf{2}$, and $\mathbf{3}$, the four-methylene protons appeared as a broad singlet, showing that one succinyl moiety had been introduced.

The position of the succinyl group was elucidated by partial hydrolysis of these compounds. Reversed-phase TLC of their hydrolyzate is shown in Fig. 1. When MDx3 was treated with $0.05 \mathrm{M} \mathrm{HCl}$ under mild conditions, the glycosidic bond was partially hydrolyzed to give a mixture of Dx0, Dx1, Dx2, and the intact starting material. When $\mathbf{1}$ and $\mathbf{2}$ were treated in the same way, Dx0 12-hemisuccinate was not produced from 1 and 3, Dx0 was only produced from 1 and both Dx0 and Dx1 from 2. Therefore, 1 and $\mathbf{2}$ were designated as the $3^{\prime}$ hemisuccinate and $3^{\prime \prime}$-hemisuccinate of MDx3, respectively. When 3 was treated in a similar fashion, Dx0 12-hemisuccinate was only produced from $\mathbf{3}$. Therefore, $\mathbf{3}$ was designated as the 12-hemisuccinate of MDx3. The results of FAB-MS of three compounds also supported these structures.

To couple the hapten with BSA, 1, 2, and $\mathbf{3}$ were transformed into their $p$-nitrophenyl esters $(\mathbf{4}-\mathbf{6})$ by treatment with $p$-nitrophenol and DCC in dioxane. These $p$-nitrophenyl esters were linked with BSA, followed by dialysis of reaction mixture against cold water to give the desired BSA conjugates (7-9).

Each immunogen thus obtained was administered to three rabbits to produce the antibody. Among the antisera elicited in rabbits, the most specific antiserum to MDx3 was selected for characterization in each group. The properties of antisera were investigated by EIA with MDx3 hemisuccinate- $\beta$-Dgalactosidase. The separation of bound and free fractions was performed using formation of an immunoprecipitate.

The standard curves of MDx3 using homologous assay by the three obtained antisera are presented in Fig. 2. Anti-

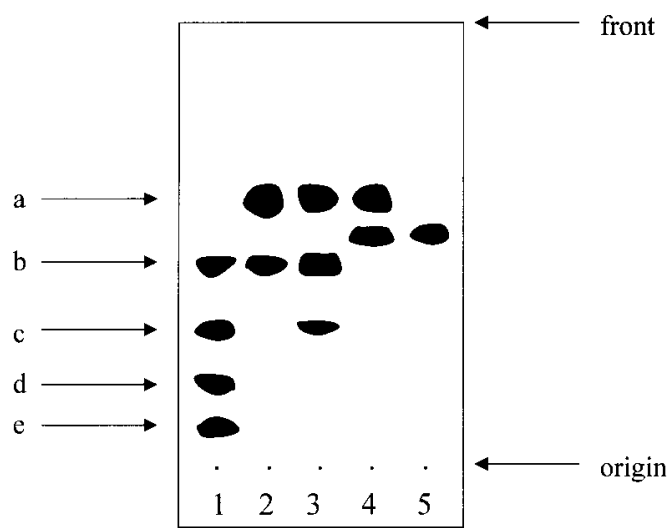

Fig. 1. Reversed-phase TLC Chromatogram of the Products Obtained by Partial Hydrolysis of MDx 3'-, 3"'-, and 12-Hemisuccinates

Plate, Whatman $\mathrm{KC}_{18}$; developing solvent, $\mathrm{MeOH}-0.5 \mathrm{M} \mathrm{NaCl}(18: 13$, v/v); visualization, spraying with concentrated sulfuric acid followed by heating in an oven at $120^{\circ} \mathrm{C}$ for $10 \mathrm{~min}$. 1 , hydrolysate of MDx $3 ; 2$, hydrolysate of MDx3 $3^{\prime}$-hemisuccinate; 3 , hydrolysate of MDx3 3"-hemisuccinate; 4, hydrolysate of MDx3 12-hemisuccinate; 5, Dx0 12-hemisuccinate. a, hemisuccinates; b, Dx0; c, Dx1; d, Dx2; e, MDx3.

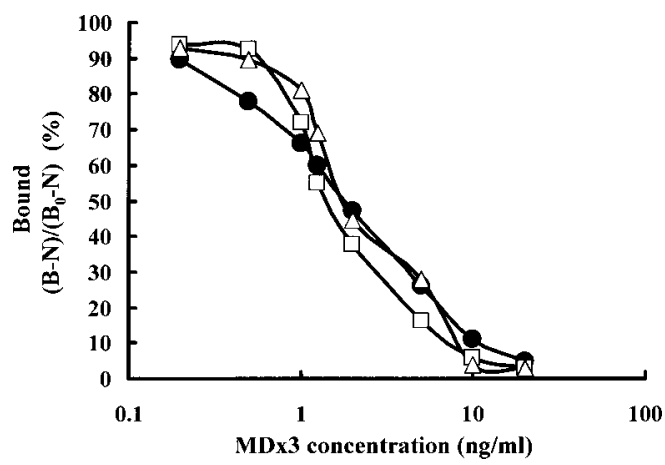

Fig. 2. Standard Curves of MDx3 by Homologous Assay Using AntiMDx3 3'-Hemisuccinate-BSA Antiserum (Antiserum-A), Anti-MDx3 3"Hemisuccinate-BSA Antiserum (Antiserum-B), and Anti-MDx3 12Hemisuccinate-BSA Antiserum (Antiserum-C)

Antiserum-A (๑), Antiserum-B ( $\triangle$ ), Antiserum-C ( $\square$ ).

serum-A, Antiserum-B, and Antiserum-C bound approximately $50 \%$ of MDx3 at final dilutions of $1: 1500,1: 15000$, $1: 2000$, respectively. The plots of percent bound fluorescence intensity vs. logarithm of the concentration of non-labeled MDx3 showed a linear relationship at range 0.2 to $20 \mathrm{ng} / \mathrm{ml}$ using Antiserum-A. However, Antiserum-B and Antiserum-C showed a linear relationship over range 0.5 to $10 \mathrm{ng} / \mathrm{ml}$. It was shown that the detection limit of AntiserumA was the best of three obtained antisera.

The specificities of Antiserum-A, Antiserum-B, and Antiserum- $C$ were assessed by cross-reaction tests with various related compounds. The percentage cross-reactivity was calculated at $50 \%$ displacement of the antibody-bound labeled MDx3, and the results are listed in Table 1. Antiserum-A possessed high specificity, exhibiting low cross-reactions with Dx2 (8.3\%), DihDx3 (4.8\%), and digitoxin (1.5\%), except for cross-reaction with Dx3 (43\%). Also, there was no significant cross-reaction with Dx1 (0.95\%). All other compounds tested showed negligible values of $<0.05 \%$. In contrast, Antiserum-B exhibited considerable cross-reactivity with Dx3 (82\%), Dx2 (65\%), Dx1 (55\%), Dx0 (58\%), and digitoxin (36\%) and low cross-reaction with DihDx3 (4.7\%). Antiserum-C showed considerable cross-reactivity with Dx3 
Table 1. Cross-reaction Data for EIA of Antiserum-A, Antiserum-B, Antiserum-C, and Antiserum-D

\begin{tabular}{lcccc}
\hline \hline & \multicolumn{4}{c}{$\%$ Cross-reactivity $(50 \%)$} \\
\cline { 2 - 5 } & Antiserum-A & Antiserum-B & Antiserum-C & Antiserum-D \\
\cline { 2 - 5 } MDx3 & 100 & 100 & 100 & 100 \\
Dx3 & 43 & 82 & 39 & 83 \\
Dx2 & 8.3 & 65 & $<0.05$ & 103 \\
Dx1 & 0.95 & 55 & $<0.05$ & 95 \\
Dx0 & $<0.05$ & 58 & $<0.05$ & 63 \\
DihDx3 & 4.8 & 4.7 & 35 & 3.7 \\
Digitoxin & 1.5 & 36 & 41 & 0.55 \\
Spironolactone & $<0.05$ & $<0.05$ & $<0.05$ & $<0.05$ \\
Digitoxose & $<0.05$ & $<0.05$ & $<0.05$ & $<0.05$ \\
Progesterone & $<0.05$ & $<0.05$ & $<0.05$ & $<0.05$ \\
Teststerone & $<0.05$ & $<0.05$ & $<0.05$ & $<0.05$ \\
Cholesterol & $<0.05$ & $<0.05$ & $<0.05$ & $<0.05$ \\
& & & & \\
\hline
\end{tabular}

Values are calculated on a molar basis.

(39\%), DihDx3 (35\%), and digitoxin (41\%). Methyl group at C-4"' of MDx3 may be poor at recognizing the obtained antibodies because of their very small molecular size. Another discussion on the cross-reaction study is that, among Antiserum-A, Antiserum-B, and Antiserum-C, Antiserum-B exhibited about two times higher cross-reactions with Dx3 ( $82 \%)$. The binding position of BSA of $\mathbf{8}$ is the nearest to the methyl group at $\mathrm{C}-4^{\prime \prime \prime}$ of $\mathrm{MDx} 3$ of $\mathbf{7 , 8} \mathbf{8}$, and $\mathbf{9}$. For this reason, Antiserum-B may be dependent on the distance between methyl group at $\mathrm{C}-4^{\prime \prime \prime}$ of $\mathrm{MDx} 3$ and the binding position of BSA. It is evident from the cross-reaction data that the antibody produced by an antigen in which the hapten is linked to a carrier protein through the digitoxose $\mathrm{C}-3^{\prime}$ position, remote from the terminal digitoxose and steroid nucleus, is able to recognize both the sugar moiety and the lactone ring of MDx3. From the present results and the previous study involving anti-digitoxin antiserum and anti-Dx3 antiserum, the C-3' position seems to be a favorable site for the attachment of BSA on the cardiac glycoside in the production of the specific antisera. $^{9-11)}$ However, the antiserum produced by MDx3-BSA conjugate possessing a bridge at the C- 3 " position near the terminal digitoxose is inferior in terms of specificity with respect to changes in the digitoxose part. The antiserum produced by the MDx3-BSA conjugate possessing a bridge at $\mathrm{C}-12$ position of steroid nucleus could not recognize the lactone ring part. These results suggest that the Antiserum-A possessed the highest specificity for $\mathrm{MDx} 3$ of these antisera, and Antiserum-A is useful to monitor MDx3 in human serum.

To investigate the precision of EIA, we performed intraand inter-assay $(n=7)$ in human at $0.5,1,2$, and $5 \mathrm{ng} / \mathrm{ml}$ by homologous assay using Antiserum-A which showed the highest selectivity to MDx3. In intra-assay, the range of coefficient variation to the average was within 4.5 to $6.9 \%$, and the recovery was within 96.2 to $103.8 \%$. In inter-assay, the range of standard deviation was $6.0-8.1 \%$, and the recovery was $97.1-104.3 \%$. These data shows that the precision of EIA is satisfactory. On the basis of these results, AntiserumD (commercial anti-Dx3 antiserum) was adopted as the standard to compare the specific properties of Antiserum-A.

The standard curves of MDx3 using Antiserum-A and Antiserum-D are presented in Fig. 3. The standard curve using

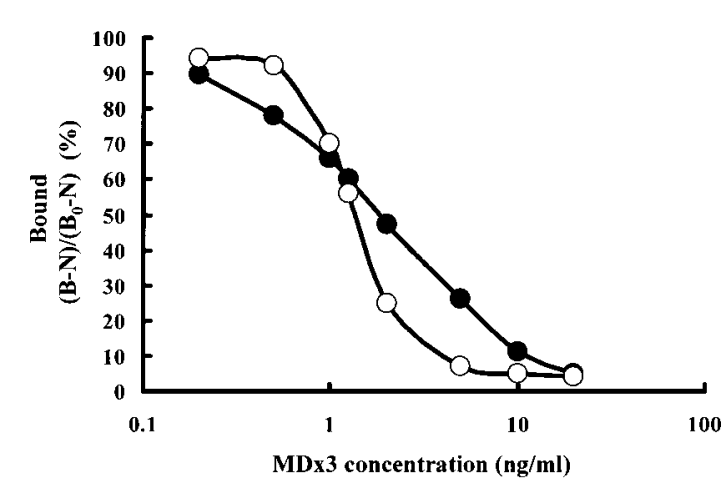

Fig. 3. Standard Curves of MDx3 Using Antiserum-A and Commercial Anti-Dx3 Antiserum (Antiserum-D)

Antiserum-A (@), Antiserum-D (O).

Antiserum-D which bound approximately $50 \%$ of MDx3 at a final dilution of $1: 500$ showed a linear relationship in the range 0.5 to $5 \mathrm{ng} / \mathrm{ml}$, while Antiserum-A showed a linear relationship in the range 0.2 to $20 \mathrm{ng} / \mathrm{ml}$. These results show that Antiserum-D has poorer sensitivity and measurable range to MDx3 as compared with those of Antiserum-A.

The percentage of cross-reactivity was calculated at $50 \%$ displacement of the antibody-bound labeled MDx3, and the results are listed in Table 1. Antiserum-D possessed much lower specificity to MDx3 compared with antiserum-A, exhibiting high cross-reactions with Dx3 (81\%), Dx2 (103\%), Dx1 (95\%), and Dx0 (63\%), and low cross-reaction with DihDx3 (3.7\%). All other compounds tested showed negligible values of $<0.05 \%$. Antiserum-D showed high cross-reactivity with metabolites formed by the successive cleavage of the digitoxose residues, indicating that Antiserum-D is much inferior to Antiserum-A in monitoring of unchanged type of MDx3, because Antiserum-D is antiserum produced by peroxidate-oxidized Dx3-BSA conjugate as an antigen at the position of terminal digitoxose. ${ }^{3)}$

As shown in Table 2, we investigated the interference of MDx 3 metabolites in human serum by using Antiserum-A and Antiserum-D. Each metabolite (Dx3, Dx2, Dx1, Dx0, and DihDx3) at ratios of $10 \%, 30 \%$ and $100 \%$ to $\mathrm{MDx} 3$ concentration were added to the MDx3 in human serum, and the recovery test was performed. The recovery ratios using Antiserum-A at $10 \%, 30 \%$, and $100 \%$ were in the range of $103-$ $110 \%, 128-146 \%$, and $175-291 \%$, respectively. In contrast, those using Antiserum-D at $10 \%, 30 \%$, and $100 \%$ were $>146 \%,>226 \%$, and $>493 \%$, respectively. These results indicate that the interference of $\mathrm{MDx} 3$ metabolites by using Antiserum-A in human serum was much lower than that of Antiserum-D, because of its low specificity to MDx3.

Antiserum-A showed much lower cross-reactivity in comparison with Antiserum-D, indicating that Antiserum-A may be used for more precise determination of intact MDx3 in human serum. However, it is considered that these low crossreactivities may result in error in the monitoring of MDx3. Removal of cross-reactive compounds in human serum is a good method. Recently, the PBA column has been used for the rapid and selective isolation of urinary catecholeamine. ${ }^{12,13)}$ Dx3, Dx2, Dx1, and DihDx3, which showed cross-reactivity (4.8-43\%), possess a cis-diol group at the terminal glycoside in the structures, while MDx3 does not. We tested rapid and selective separation of MDx3 from mix- 
Table 2. Interference of MDx3 Metabolites on the Assay of MDx3 in Human Serum

\begin{tabular}{|c|c|c|c|c|}
\hline \multirow{2}{*}{ Added } & \multicolumn{2}{|c|}{ Antiserum-A } & \multicolumn{2}{|c|}{ Antiserum-D } \\
\hline & $\begin{array}{l}\text { Measured }(\mathrm{ng} / \mathrm{ml}) \\
\text { mean } \pm \text { S.D. }(n=7)\end{array}$ & $\begin{array}{l}\text { Recovery } \\
(\%)\end{array}$ & $\begin{array}{l}\text { Measured }(\mathrm{ng} / \mathrm{ml}) \\
\text { mean } \pm \text { S.D. }(n=7)\end{array}$ & $\begin{array}{c}\text { Recovery } \\
(\%)\end{array}$ \\
\hline \multicolumn{5}{|l|}{$\operatorname{MDx} 3(0.5 \mathrm{ng} / \mathrm{ml})$} \\
\hline + Metabolites (each $0.05 \mathrm{ng} / \mathrm{ml})$ & $0.55 \pm 0.03$ & 110 & $0.73 \pm 0.06$ & 146 \\
\hline+ Metabolites (each $0.15 \mathrm{ng} / \mathrm{ml})$ & $0.68 \pm 0.06$ & 136 & $1.20 \pm 0.10$ & 240 \\
\hline +Metabolites (each $0.5 \mathrm{ng} / \mathrm{ml})$ & $0.88 \pm 0.07$ & 175 & $2.47 \pm 0.21$ & 493 \\
\hline \multicolumn{5}{|l|}{$\operatorname{MDx} 3(1 \mathrm{ng} / \mathrm{ml})$} \\
\hline + Metabolites (each $0.1 \mathrm{ng} / \mathrm{ml})$ & $1.07 \pm 0.06$ & 108 & $1.48 \pm 0.11$ & 148 \\
\hline + Metabolites (each $0.3 \mathrm{ng} / \mathrm{ml}$ ) & $1.36 \pm 0.12$ & 136 & $2.26 \pm 0.20$ & 226 \\
\hline +Metabolites (each 1 ng/ml) & $2.09 \pm 0.16$ & 209 & $>5.0$ & $(-)$ \\
\hline \multicolumn{5}{|l|}{$\operatorname{MDx} 3(2 \mathrm{ng} / \mathrm{ml})$} \\
\hline +Metabolites (each $0.2 \mathrm{ng} / \mathrm{ml})$ & $2.06 \pm 0.14$ & 103 & $3.85 \pm 0.34$ & 192.5 \\
\hline +Metabolites (each $0.6 \mathrm{ng} / \mathrm{ml}$ ) & $2.92 \pm 0.24$ & 146 & $>5.0$ & $(-)$ \\
\hline +Metabolites (each 2 ng/ml) & $4.74 \pm 0.40$ & 237 & $>5.0$ & $(-)$ \\
\hline \multicolumn{5}{|l|}{ MDx3 (5 ng/ml) } \\
\hline +Metabolites (each $0.5 \mathrm{ng} / \mathrm{ml})$ & $5.17 \pm 0.34$ & 103 & $>5.0$ & $(-)$ \\
\hline +Metabolites (each $1.5 \mathrm{ng} / \mathrm{ml})$ & $6.39 \pm 0.55$ & 128 & $>5.0$ & $(-)$ \\
\hline +Metabolites (each $5 \mathrm{ng} / \mathrm{ml})$ & $14.6 \pm 1.21$ & 291 & $>5.0$ & $(-)$ \\
\hline
\end{tabular}

Metabolites: Dx3, Dx2, Dx1, Dx0, and DihDx3.

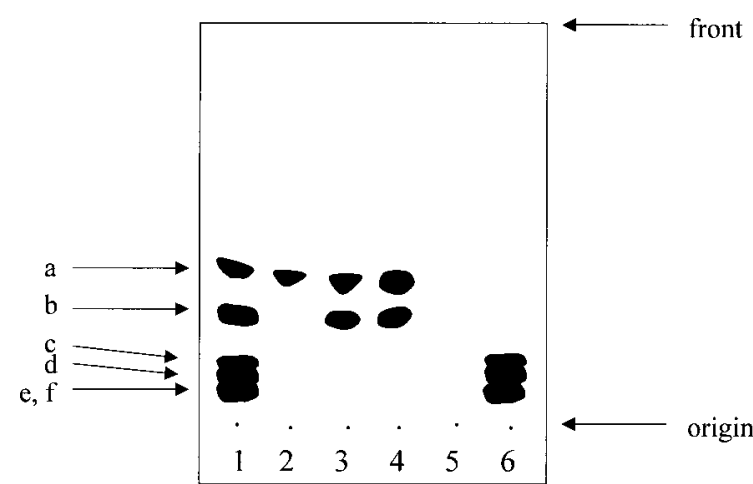

Fig. 4. Rapid and Selective Separation of MDx3 from Mixtures of MDx3 and Its Metabolites in Human Serum Using PBA Column Treatment

Merck HPTLC (silica-gel); developing solvent, $\mathrm{CHCl}_{3}-\mathrm{MeOH}-\mathrm{H}_{2} \mathrm{O}$ (85: $15: 1$, v/v); visualization, spraying with concentrated sulfuric acid followed by heating in an oven at $120^{\circ} \mathrm{C}$ for 10 min. 1 , mixtures of MDx3, Dx3, Dx2, Dx1, Dx0, DihDx3; 2, PBA column treatment by $\mathrm{CH}_{3} \mathrm{CN}(1 \mathrm{ml}) ; 3$, PBA column treatment washed by $\mathrm{CH}_{3} \mathrm{CN}(1 \mathrm{ml})$; 4, PBA column treatment washed by $\mathrm{CH}_{3} \mathrm{CN}(1 \mathrm{ml}) ; 5$, PBA column treatment washed by $\mathrm{CH}_{3} \mathrm{CN}(1 \mathrm{ml}) ; 6$, PBA column treatment washed by $\mathrm{CH}_{3} \mathrm{OH}(1 \mathrm{ml})$. a, $\mathrm{MDx} 3 ; \mathrm{b}$, Dx0; c, Dx1; d, Dx2; e, Dx3; f, DihDx3.

tures of MDx3 and its metabolites in human serum using a PBA column. Adding whole $\mathrm{CH}_{3} \mathrm{CN}$ solution to a PBA column after extraction of the human serum with AcOEt, evaporation of the extracted organic layer, and addition of $1 \mathrm{ml}$ of $\mathrm{CH}_{3} \mathrm{CN}$ to a test tube, we could detect MDx3 only on HPTLC as shown in Fig. 4. By the second addition of $1 \mathrm{ml}$ of $\mathrm{CH}_{3} \mathrm{CN}$ to PBA column, we could detect MDx3 and Dx0 on HPTLC. By the third addition, we could detect MDx3 and Dx0 on HPTLC. However, using the same procedure 4 times, nothing could be detected on HPTLC. Dx3, Dx2, Dx1, and DihDx3 could be detected on HPTLC by washing the column with $\mathrm{MeOH}$ after eluent of $\mathrm{CH}_{3} \mathrm{CN}$ solution at 4 times, indicating that these compounds interacted with boric acids in the PBA column because they possess a cis-diol group. These results suggest that $\mathrm{MDx} 3$ and $\mathrm{Dx} 0$, which did not possess a cis-diol group in the molecular structure, can be selectively separated from the mixture of MDx3 and its metabolites in human serum by PBA column treatment.
Table 3. Recovery of MDx3 in Phosphate Buffer and Human Serum by Homologous Assay Using Antiserum-A after PBA Column Treatment

In phosphate buffer $(n=9)$

\begin{tabular}{lccc}
\hline \hline Added (ng/ml) & $\begin{array}{c}\text { Measured (ng/ml) } \\
\text { mean } \pm \text { S.D. }\end{array}$ & C.V. (\%) & Recovery (\%) \\
\hline 0.5 & $0.51 \pm 0.05$ & 9.4 & 102 \\
1 & $0.97 \pm 0.08$ & 8.2 & 97.3 \\
2 & $2.06 \pm 0.19$ & 9.3 & 103 \\
5 & $5.20 \pm 0.50$ & 9.7 & 104 \\
\hline
\end{tabular}

In human serum $(n=9)$

\begin{tabular}{cccc}
\hline \hline Added (ng/ml) & $\begin{array}{c}\text { Measured (ng/ml) } \\
\text { mean } \pm \text { S.D. }\end{array}$ & C.V. (\%) & Recovery (\%) \\
\hline 0.5 & $0.54 \pm 0.04$ & 9.7 & 108 \\
1 & $1.12 \pm 0.11$ & 9.3 & 112 \\
2 & $2.20 \pm 0.20$ & 9.0 & 110 \\
5 & $5.61 \pm 0.53$ & 9.5 & 112 \\
\hline
\end{tabular}

About $4 \mathrm{ml}$ of $\mathrm{CH}_{3} \mathrm{CN}$ solution developed in the PBA column were collected and evaporated in vacuo. Then, MDx3 was measured by homologous EIA using Antiserum-A after PBA column treatment in phosphate buffer and human serum was investigated. The data are listed in Table 3. Recovery rates in phosphate buffer and human serum were about $100 \%$ and about $110 \%$, respectively. As shown in Table 4, we investigated the effect of PBA column treatment on the interference of metabolites. Each metabolite (Dx3, Dx2, Dx1, Dx0, and DihDx3) at an equal concentration with the MDx3 concentration was added to the MDx3 in human serum, and the recovery test was performed. The recovery ratios at non-PBA column treatment and PBA column treatment were in the range of and $175-291 \%$ and $107-114 \%$, respectively These data indicated that no significant interference by metabolites of MDx3 in our EIA was confirmed.

When PBA column was used for the pretreatment of human serum sample containing Dx3, Dx2, Dx1, Dx0, and 
Table 4. Interference of MDx3 Metabolites on the Assay of MDx3 by Homologous Assay Using Antiserum-A in Human Serum after PBA Column Treatment

\begin{tabular}{|c|c|c|c|c|c|c|}
\hline \multirow[b]{2}{*}{ Added } & \multicolumn{3}{|c|}{ Non-PBA Treatment } & \multicolumn{3}{|c|}{ PBA Treatment } \\
\hline & $\begin{array}{l}\text { Measured }(\mathrm{ng} / \mathrm{ml}) \\
\text { mean } \pm \text { S.D. }(n=7)\end{array}$ & $\begin{array}{l}\text { C.V. } \\
(\%)\end{array}$ & $\begin{array}{l}\text { Recovery } \\
(\%)\end{array}$ & $\begin{array}{l}\text { Measured }(\mathrm{ng} / \mathrm{ml}) \\
\text { mean } \pm \text { S.D. }(n=7)\end{array}$ & $\begin{array}{l}\text { C.V. } \\
(\%)\end{array}$ & $\begin{array}{c}\text { Recovery } \\
(\%)\end{array}$ \\
\hline \multicolumn{7}{|l|}{$\operatorname{MDx} 3(0.5 \mathrm{ng} / \mathrm{ml})$} \\
\hline+ Metabolites (each $0.5 \mathrm{ng} / \mathrm{ml})$ & $0.88 \pm 0.07$ & 8.0 & 175 & $0.54 \pm 0.05$ & 9.3 & 107 \\
\hline \multicolumn{7}{|l|}{$\operatorname{MDx} 3(1 \mathrm{ng} / \mathrm{ml})$} \\
\hline +Metabolites (each $1 \mathrm{ng} / \mathrm{ml})$ & $2.09 \pm 0.16$ & 7.7 & 209 & $1.10 \pm 0.10$ & 9.1 & 110 \\
\hline \multicolumn{7}{|l|}{$\operatorname{MDx} 3(2 \mathrm{ng} / \mathrm{ml})$} \\
\hline + Metabolites (each 2 ng/ml) & $4.74 \pm 0.40$ & 8.4 & 237 & $2.28 \pm 0.21$ & 9.2 & 114 \\
\hline \multicolumn{7}{|l|}{ MDx3 (5 ng/ml) } \\
\hline + Metabolites (each $5 \mathrm{ng} / \mathrm{ml})$ & $14.6 \pm 1.21$ & 8.3 & 291 & $5.62 \pm 0.48$ & 8.5 & 112 \\
\hline
\end{tabular}

Metabolites: Dx3, Dx2, Dx1, Dx0, and DihDx3.

DihDx3, MDx3 and Dx0 were separated (Fig. 4). AntiserumD showed high cross-reactivity with Dx0 (63\%), while Antiserum-A showed negligible value of $<0.05 \%$. It is considered that EIA by Antiserum-D using PBA column shows the significant measurement error. In addition, the measurement range of EIA by Antiserum-A $(0.2-20 \mathrm{ng} / \mathrm{ml})$ is much sensitive compared with that of Antiserum-D $(0.5-5 \mathrm{ng} / \mathrm{ml})$. In these points, Antiserum-A of our novel specific antiserum is superior to Antiserum-D.

Consequently, our results suggest that unchanged type of MDx3 concentration in human serum after administration will be more precisely monitored using both Antiserum-A and PBA column treatment. We expect that our newly developed assay system for MDx3 will be clinically popularized in the world in the near future.

Acknowledgements This work was supported in part by the Special Research Fund of Hokuriku University.

\section{REFERENCES}

1) Valdes R., Jr., Brown B. A., Graves S. W., Am. J. Clin. Pathol., 82, 210-213 (1984).

2) Wahyono D., Piechaczyk M., Mourton C., Bastide J. M., Pau B., Hybridoma, 9, 619-629 (1990).

3) Miller J. J., Straub R. W., Jr., Valdes R., Jr., Clin. Chem., 40, 18981903 (1994).

4) Gault M. H., Longerich L. L., Loo J. C. K., Ko P. T. H., Fine A., Vasdev S. C., Dawe M. A., Clin. Pharmacol. Ther, 35, 74-82 (1984).

5) Hinderling P. H., Garrett E. R., Wester R. C., J. Pharm. Sci., 66, 242253 (1977).

6) Hinderling P. H., Garrett E. R., Wester R. C., J. Pharm. Sci., 66, 314 325 (1977).

7) Shimada K., Mizusawa S., Ohkubo T., Nambara T., Chem. Pharm. Bull., 32, 2301-2306 (1984).

8) Thong B., Soldin S. J., Lingwood C. A., Clin. Chem., 31, 1625-1631 (1985).

9) Ikeda Y., Fujii Y., Biol. Pharm. Bull., 23, 906-910 (2000).

10) Fujii Y., Ikeda Y., Yamazaki M., Clin. Chem., 40, 172-173 (1994).

11) Fujii Y., Ikeda Y., Fujii M., Yamazaki M., Biol. Pharm. Bull., 17, 467-471 (1994).

12) Dimson P. A., Analytichem. International (Current), 3, 4-5 (1984).

13) Alan H. B. W., Terrie G. G., Clin. Chem., 31, 298-302 (1985).

14) Haack E., Kaiser F., Spingler H., Naturwissenschaften, 44, 633-634 (1957). 